Delft University of Technology

\title{
Performance assessment on high strength steel endplate connections after fire
}

Qiang, Xuhong; Wu, N.; Jiang, Xu; Bijlaard, Frans; Kolstein, Henk

DOI

10.1108/JSFE-11-2016-0018

Publication date

2017

Document Version

Final published version

Published in

Journal of Structural Fire Engineering

\section{Citation (APA)}

Qiang, X., Wu, N., Jiang, X., Bijlaard, F., \& Kolstein, H. (2017). Performance assessment on high strength steel endplate connections after fire. Journal of Structural Fire Engineering, 8(2), 202-214.

https://doi.org/10.1108/JSFE-11-2016-0018

\section{Important note}

To cite this publication, please use the final published version (if applicable).

Please check the document version above.

\section{Copyright}

Other than for strictly personal use, it is not permitted to download, forward or distribute the text or part of it, without the consent of the author(s) and/or copyright holder(s), unless the work is under an open content license such as Creative Commons.

\section{Takedown policy}

Please contact us and provide details if you believe this document breaches copyrights.

We will remove access to the work immediately and investigate your claim. 


\section{e emeraldinsight}

\section{Journal of Structural Fire Engineering}

Performance assessment on high strength steel endplate connections after fire

Xuhong Qiang, Nianduo Wu, Xu Jiang, Frans Bijlaard, Henk Kolstein,

\section{Article information:}

To cite this document:

Xuhong Qiang, Nianduo Wu, Xu Jiang, Frans Bijlaard, Henk Kolstein, (2017) "Performance assessment on high strength steel endplate connections after fire", Journal of Structural Fire

Engineering, Vol. 8 Issue: 2, pp.202-214, https://doi.org/10.1108/JSFE-11-2016-0018

Permanent link to this document:

https://doi.org/10.1108/JSFE-11-2016-0018

Downloaded on: 10 J une 2017, At: 06:23 (PT)

References: this document contains references to 20 other documents.

To copy this document: permissions@emeraldinsight.com

The fulltext of this document has been downloaded 29 times since 2017*

Access to this document was granted through an Emerald subscription provided by emeraldsrm: 359104 []

\section{For Authors}

If you would like to write for this, or any other Emerald publication, then please use our Emerald for Authors service information about how to choose which publication to write for and submission guidelines are available for all. Please visit www. emeraldinsight.com/authors for more information.

\section{About Emerald www.emeraldinsight.com}

Emerald is a global publisher linking research and practice to the benefit of society. The company manages a portfolio of more than 290 journals and over 2,350 books and book series volumes, as well as providing an extensive range of online products and additional customer resources and services.

Emerald is both COUNTER 4 and TRANSFER compliant. The organization is a partner of the Committee on Publication Ethics (COPE) and also works with Portico and the LOCKSS initiative for digital archive preservation.

*Related content and download information correct at time of download. 
JSFE

8,2

\section{2}

Received 10 November 2016

Revised 9February 2017

Accepted 22 February 2017

\section{Performance assessment on high strength steel endplate connections after fire}

\author{
Xuhong Qiang \\ Department of Structural Engineering, College of Civil Engineering, \\ Tongji University, Shanghai, China \\ and Department of Structural Engineering, Technische Universiteit Delft, \\ Delft, The Netherlands \\ Nianduo $\mathrm{Wu}$ \\ College of Civil Engineering, Tongji University, Shanghai, China \\ $\mathrm{Xu}$ Jiang \\ Department of Bridge Engineering, College of Civil Engineering, \\ Tongji University, Shanghai, China \\ and Department of Structural Engineering, Technische Universiteit Delft, \\ Delft, The Netherlands, and \\ Frans Bijlaard and Henk Kolstein \\ Department of Structural Engineering, Technische Universiteit Delft, \\ Delft, The Netherlands
}

\begin{abstract}
Purpose - This study aims to reveal more information and understanding on performance and failure mechanisms of high strength steel endplate connections after fire.

Design/methodology/approach - An experimental and numerical study on seven endplate connections after cooling down from fire temperature of $550^{\circ} \mathrm{C}$ has been carried out and reported herein. Moreover, the provisions of European design standard for steel structures, Eurocode 3, were validated with test results of high strength steel endplate connections.

Findings - In endplate connections, a proper design using a thinner high strength steel endplate can achieve the same failure mode, similar residual load bearing capacity and comparable or even higher rotation capacity after cooling down from fire. It is found that high strength steel endplate connection can regain more than 90 per cent of its original load bearing capacity after cooling down from fire temperature of $550^{\circ} \mathrm{C}$.

Originality/value - The post-fire performance of high strength steel endplate connection has been reported. The accuracy of Eurocode 3 for endplate connections is validated against test results.
\end{abstract}

Keywords Numerical study, Experimental study, High strength steel, After fire,

Endplate connection

Paper type Research paper

\title{
1. Introduction
}

For the time being, high strength steels are more and more popular in mechanical Engineering Vol. 8 No. 2, 2017 pp. $202-214$

(c) Emerald Publishing Limited 2040-2317

DOI 10.1108/JSFE-11-2016-0018 strength steels have been used in some significant structures and landmark constructions, such as the New York Freedom Tower, the Beijing Bird's Nest Olympic Stadium and the 
French cable-stayed road-bridge Millau Viaduct. However, in current literature of civil engineering, there are very limited reports on the performance of high strength steel structures. The research status will retard the application of these high strength materials in civil engineering or lead to an uneconomical design of high strength steel structures.

Since 9.11 tragedy, structural fire safety has been a worldwide key consideration in the design of building structures. Provided that collapse does not occur when a steel structure is exposed to fire, the steel members will begin to cool once the fire starts to decay and the air temperature begins to decrease. Residual forces and deformations redevelop in steel structures during the cooling phase because of the shrinkage of the steel members, which might be more dangerous conditions than in fire. If all the structures exposed to fire are dismantled and then new alternates are built, it is wasteful and time-consuming, whereas if the post-fire structures are reused directly or simply reinforced, it may be safety-compromised, which makes people feel unsafe when they step into the structures. Whether the structures exposed to fire should be demolished, repaired or reused directly, a reliable assessment is needed.

However, in the leading design standards of steel structures all over the world, only the former British Standard 5950: Part 8 (BS Institution, 1998) has a suggestion about the reuse of structural steels after fire. According to it, hot finished steels and cast steel can be reused after fire if the distortions remain within the tolerances for straightness and shape. For mild steel S235 and S275, it is said that they can be assumed to be able to regain at least 90 per cent of their mechanical properties. Similarly, for S355, it is said that it can be assumed at least 75 per cent of the strength is regained on cooling from temperatures above $600^{\circ} \mathrm{C}$. But no assumption or suggestion is given for high strength steels in any current design standard of steel structures all over the world. In current literature, the available studies on post-fire performance of building structures are very few and mainly focus on steel-concrete composite joints (Pucinotti et al., 2011), concrete-filled steel tubular columns (Tao et al., 2011; Yang et al., 2008) and mild steel frames (Della Corte et al., 2003). By now, no research report on post-fire performance of high strength steel structures is available in literature.

In Europe, endplate connections are typical beam-to-column connections for steel structures produced by welding at workshops and erected by bolting in situ. The simplicity and economy associated with its fabrication make this type of connection popular in steel structures. Hence, the post-fire performance of high strength steel endplate connections is assessed herein to reveal their residual performance after fire, which is a basis for evaluating the residual performance of an entire structure after cooling down from fire.

First, full-scale tests on seven endplate connections were carried out after cooling down from fire temperature of $550^{\circ} \mathrm{C}$ to evaluate their post-fire performance. The moment resistance, rotation capacity and failure mode of high strength steel endplate connections after fire were obtained via tests and compared with those of mild steel endplate connections, as well as with their original performance at ambient temperature without fire exposure. Moreover, the provisions of European design standard for steel structures, Eurocode 3, which were mainly obtained based on the mild steel structures, were validated with test results of high strength steel endplate connections. Furthermore, a numerical study on high strength steel endplate connections after fire conducted via the commercial package ABAQUS (2013) is reported. The main characteristics of the finite element model, such as geometry, materials, mesh, element, contact interaction and analysis progress, are described in detail. The accuracy of this numerical modeling was validated against the experimental results on moment-rotation relationship, failure mode and yield line pattern of endplate connections. 
JSFE

8,2

204

\section{Experimental study}

\subsection{Test specimen}

The endplate connections were designed according to Eurocode 3: Part 1:8 (CEN, 2005). All specimens were designed to confine failure to the connections (particularly to the endplates in tensile zone) rather than the beam or column. In the high strength steel endplate connections, the endplates are made of high strength steels (S690 and S960), while the beam and column are made of Q345 (similar to S355). The beam sections used in this experimental study are HW300 $\times 300$ ( $\mathrm{h}=300 \mathrm{~mm}, \mathrm{~b}=300 \mathrm{~mm}, \mathrm{tw}=10 \mathrm{~mm}, \mathrm{tf}=15 \mathrm{~mm}$, comparable to European Section HE320A), and the column sections are HW400 $\times 400(\mathrm{~h}=428 \mathrm{~mm}, \mathrm{~b}=407 \mathrm{~mm}, \mathrm{tw}=20 \mathrm{~mm}$, tf $=35 \mathrm{~mm}$, comparable to European Section HE400M). For comparison, the connections with endplates made of mild steels Q235 (similar to S235) and Q345 (similar to S355) are also included herein. To compare the performance of endplate connections after fire with that without exposure to fire, the tests at ambient temperature without fire exposure on each concerned endplate connection were carried out as well. The detailed drawing of endplate connection test specimen is shown in Figure 1, while the characteristics and test conditions of the specimens are shown in Table I.

\subsection{Test set-up and procedure}

The heating process was conducted in a gas furnace $(4.5 \times 3.0 \times 1.7 \mathrm{~m})$. As applying a tensile load under fire conditions is more stable than applying a compressive load, the connection specimens were designed to be located upside down to easily apply the tensile load from the outside of the furnace, as shown in Figure 2.

The specimen was first heated to $550^{\circ} \mathrm{C}$ at a constant heating rate of $10^{\circ} \mathrm{C} / \mathrm{min}$ [which corresponds to normally protected steel members in fire (Witteveen et al., 1976)], after the temperature of connection components achieved $550^{\circ} \mathrm{C}$ and was stable for an hour, the heating was stopped and the specimens began to cool down to ambient temperature, where the cooling method was natural cooling. After cooling down, the post-fire connection specimens were loaded at ambient temperature until failure to evaluate the residual load bearing capacity, displacement, rotation and failure modes of high strength steel endplate connections after cooling down from fire.

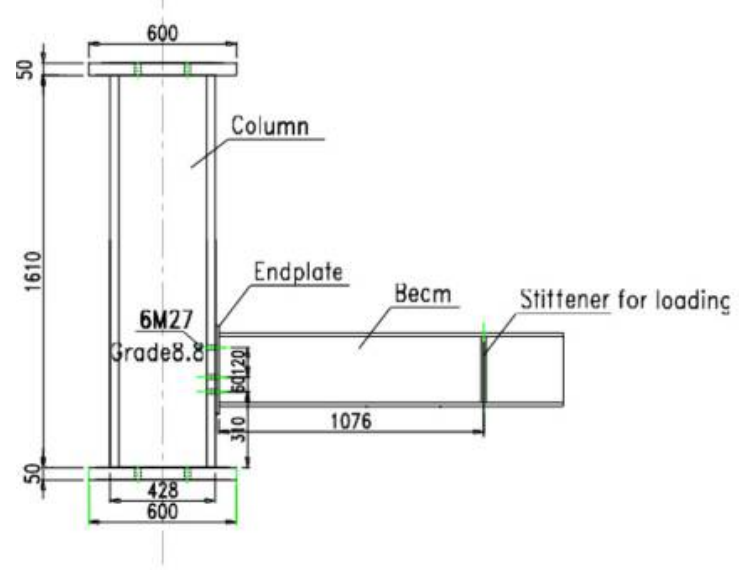

(a)

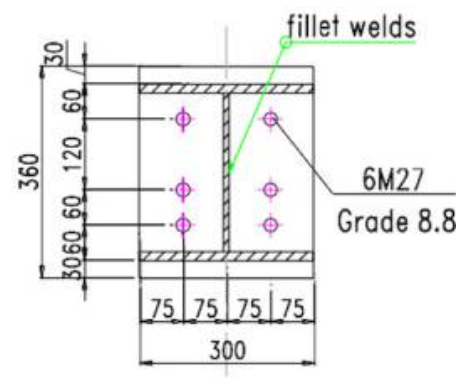

(b)
Endplate connection specimen

Notes: (a) Endplate connection; (b) Endplate 


\begin{tabular}{|c|c|c|c|c|c|}
\hline Test ID & $\begin{array}{l}\text { Endplate } \\
\text { material }\end{array}$ & $\begin{array}{l}\text { Endplate thickness } \\
\qquad(\mathrm{mm})\end{array}$ & Weld type & $\begin{array}{l}\text { Highest fire } \\
\text { temperature } \\
\left({ }^{\circ} \mathrm{C}\right) \text { in post- } \\
\text { fire tests }\end{array}$ & $\begin{array}{c}\text { Temperature }\left({ }^{\circ} \mathrm{C}\right) \text { of } \\
\text { specimens in } \\
\text { ambient tests } \\
\text { without fire } \\
\text { exposure }\end{array}$ \\
\hline $1-1 \mathrm{P}$ & Q235 & 20 & Overmatched & 550 & - \\
\hline $1-2 \mathrm{P}$ & S690 & 12 & Matched & 550 & - \\
\hline $1-3 \mathrm{P}$ & S960 & 10 & Under matched & 550 & - \\
\hline $2-1 \mathrm{P}$ & Q235 & 25 & Overmatched & 550 & - \\
\hline $2-2 \mathrm{P}$ & Q345 & 20 & Overmatched & 550 & - \\
\hline $2-3 \mathrm{P}$ & S690 & 15 & Matched & 550 & - \\
\hline $2-4 \mathrm{P}$ & S960 & 12 & Under matched & 550 & - \\
\hline $1-1 \mathrm{~A}$ & Q235 & 20 & Overmatched & - & 20 \\
\hline $1-2 \mathrm{~A}$ & $\mathrm{~S} 690$ & 12 & Matched & - & 20 \\
\hline $1-3 \mathrm{~A}$ & S960 & 10 & Under matched & - & 20 \\
\hline $2-1 \mathrm{~A}$ & Q235 & 25 & Overmatched & - & 20 \\
\hline $2-2 \mathrm{~A}$ & Q345 & 20 & Overmatched & - & 20 \\
\hline $2-3 \mathrm{~A}$ & S690 & 15 & Matched & - & 20 \\
\hline $2-4 \mathrm{~A}$ & S960 & 12 & Under matched & - & 20 \\
\hline
\end{tabular}
ambient tests

assessment

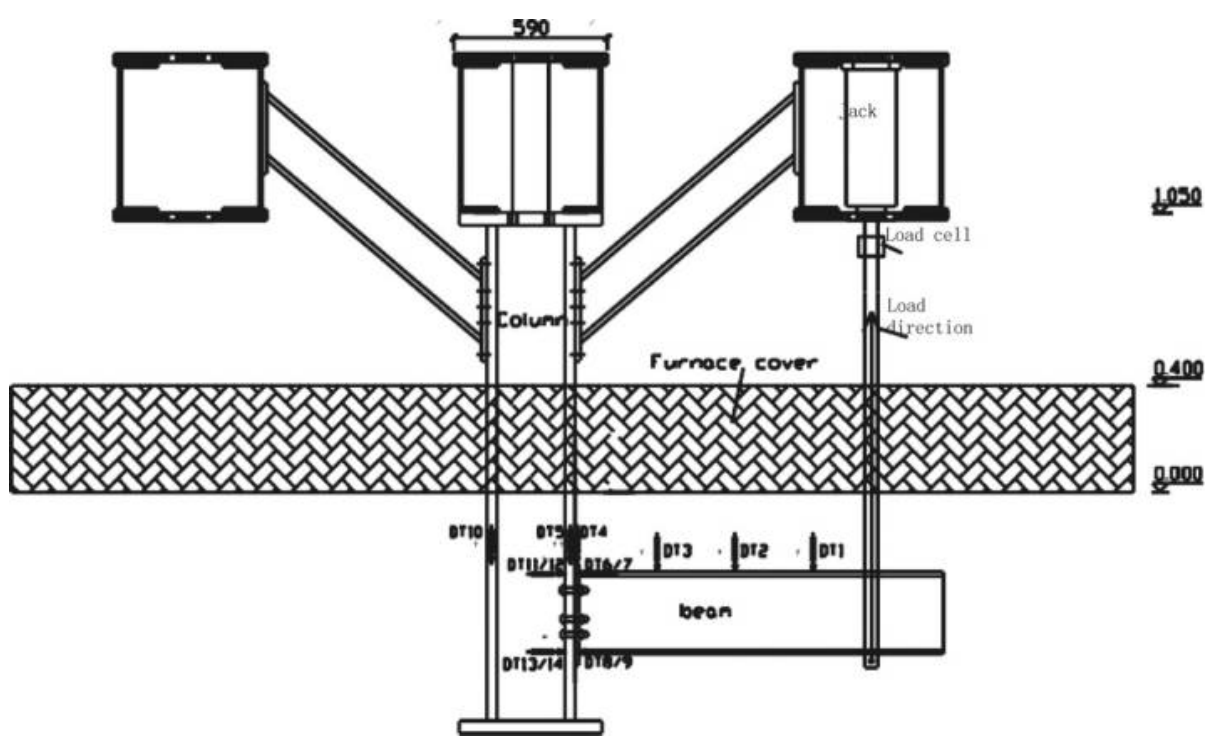

Table I.

Test specimens and test conditions

Figure 2. Fire test set-up

\subsection{Displacement measurement}

In the fire tests, three vertical displacement sensors (DT1-DT3) were used to obtain the vertical displacement of the beam, as shown in Figure 2. According to the vertical displacements of beam, the rotation of beam can be calculated. To record the displacement of column, two vertical displacement sensors (DT5 and DT10) were arranged. According to the displacement of column, the rotation of column can be calculated. To measure the displacement of endplate, one vertical displacement sensor (DT4) and four horizontal displacement sensors (DT6-DT9) were placed, as shown in 
JSFE 8,2

206

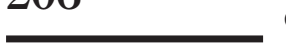

\section{Table II.}

Description of components at the end of tests
Figure 2. According to the displacement of endplate, the rotation of endplate can be calculated. Based on the displacements of the aforementioned components, the rotation of endplate connection in tests can be obtained.

\subsection{Test results}

2.4.1 Deformation at the end of tests. For all endplate connections after fire, their final deformation states were photographed at the end of tests at ambient temperature after cooling down from fire and are presented in Qiang (2013); the final deformation states of endplate connections at ambient temperature without fire exposure were addressed as well. An overall description on components of all connections at the end of the tests is listed in Table II, including post-fire tests and ambient tests.

2.4.2 Moment-rotation relationship of endplate connections. The tested characteristics of moment-rotation relationship for all endplate connections after cooling down from elevated temperature of $550^{\circ} \mathrm{C}$ are presented in Table III. The post-fire moment-rotation comparison of the connections in Series 1 is shown in Figure 3. It can be seen that their load bearing capacities are similar, while the maximum rotational capacity of connection 1-2 P (S690 12 $\mathrm{mm}$ ) is higher than that of connection 1-1 P (Q235 $20 \mathrm{~mm})$. In tests, the post-fire connection S960 $10 \mathrm{~mm}$ failed because of cracking of the endplate at the heat affected zone of welds after a moderate amount of plastic deformation on the endplate, which will be addressed hereafter. Therefore, its rotation capacity is relatively low and not included in the comparison. The moment-rotation comparison of connections in Series 2 after cooling down from fire is presented in Figure 4. It can be found that the post-fire load bearing capacities of connections in Series 2 are similar to each other. The post-fire rotational capacities of connections 2-1 P (Q235 $25 \mathrm{~mm}$ ), 2-2 P (Q345 $20 \mathrm{~mm}$ ) and 2-3 P (S690 $15 \mathrm{~mm}$ ) are in a comparable range, while that of connection 2-4 P (S960 $12 \mathrm{~mm}$ ) is higher than the others in connection Series 2.

A conclusion can be drawn that in endplate connections, a proper thinner endplate made of high strength steel can achieve similar post-fire load bearing capacity and higher (or at least comparable) post-fire maximum rotational capacity in comparison with a thicker endplate made of mild steel.

\begin{tabular}{|c|c|c|c|c|c|c|c|}
\hline Test ID & $\begin{array}{l}\text { Endplate } \\
\text { material }\end{array}$ & $\begin{array}{c}\text { Endplate } \\
\text { thickness } \\
\text { (mm) }\end{array}$ & $\begin{array}{l}\text { Endplate } \\
\text { yielding }\end{array}$ & $\begin{array}{l}\text { Fracture of } \\
\text { bolts in top } \\
\text { tensile row }\end{array}$ & $\begin{array}{l}\text { Nuts in top } \\
\text { tensile row } \\
\text { stripped } \\
\text { off }\end{array}$ & $\begin{array}{l}\text { Weld failure } \\
\text { in heat } \\
\text { affected } \\
\text { zone }\end{array}$ & $\begin{array}{l}\text { Bolts in } \\
\text { compression } \\
\text { almost } \\
\text { straight }\end{array}$ \\
\hline $1-1 \mathrm{P}$ & Q235 & 20 & Yes & No & No & No & Yes \\
\hline $1-2 \mathrm{P}$ & S690 & 12 & Yes & No & Yes & No & Yes \\
\hline $1-3 \mathrm{P}$ & S960 & 10 & Yes & No & No & Yes & Yes \\
\hline $2-1 \mathrm{P}$ & Q235 & 25 & Yes & Yes & No & No & Yes \\
\hline $2-2 \mathrm{P}$ & Q345 & 20 & Yes & Yes & No & No & Yes \\
\hline $2-3 \mathrm{P}$ & S690 & 15 & Yes & Yes & No & No & Yes \\
\hline $2-4 \mathrm{P}$ & S960 & 12 & Yes & No & Yes & No & Yes \\
\hline 1-1 A & Q235 & 20 & Yes & No & No & No & Yes \\
\hline $1-2 \mathrm{~A}$ & S690 & 12 & Yes & No & Yes & No & Yes \\
\hline $1-3 \mathrm{~A}$ & S960 & 10 & Yes & No & No & Yes & Yes \\
\hline 2-1 A & Q235 & 25 & Yes & Yes & No & No & Yes \\
\hline $2-2 \mathrm{~A}$ & Q345 & 20 & Yes & Yes & No & No & Yes \\
\hline 2-3 A & S690 & 15 & Yes & Yes & No & No & Yes \\
\hline $2-4 \mathrm{~A}$ & S960 & 12 & Yes & Yes & No & No & Yes \\
\hline
\end{tabular}




\section{Numerical study}

The finite element software package ABAQUS (2013) 6.8 was used to numerically simulate the performance of high strength steel endplate connections after fire and at ambient temperature as well.

\subsection{Finite element model}

The geometric details of all connections' components modeled using finite equation modeling are the same as those of the test specimens. Because the geometric details, load, temperature distribution and boundary conditions of the beam-to-column endplate connection are symmetric, half of the endplate connection was modeled to reduce computer costs. There are seven surface-to-surface contact interactions and seven tie interactions in this finite element model, and the materials are endowed with non-linear properties. The whole connection was modeled using C3D8I elements.

\begin{tabular}{llcccc}
\hline & \multicolumn{2}{c}{ Endplate } & \multicolumn{2}{c}{ Peak load } & \\
Test ID & Material & Thickness $(\mathrm{mm})$ & $\begin{array}{c}\text { Moment } \\
(\mathrm{kN} \cdot \mu \mathrm{m})\end{array}$ & Force $(\mathrm{kN})$ & $\begin{array}{c}\text { Connection } \\
\text { rotation } \boldsymbol{\phi}_{C}(\mathrm{mrad})\end{array}$ \\
\hline $1-1 \mathrm{P}$ & Q235 & 20 & 255.56 & 237.51 & 249 \\
$1-2 \mathrm{P}$ & S690 & 12 & 226.67 & 210.66 & 397 \\
$1-3 \mathrm{P}$ & S960 & 10 & 230.80 & 214.50 & 147 \\
2-1 P & Q235 & 25 & 272.59 & 253.34 & 150 \\
$2-2 \mathrm{P}$ & Q345 & 20 & 272.35 & 253.11 & 139 \\
$2-3 \mathrm{P}$ & S690 & 15 & 261.79 & 243.30 & 141 \\
$2-4 \mathrm{P}$ & S960 & 12 & 252.85 & 234.99 & 238
\end{tabular}

Figure 3.

Moment-rotation comparison of connection Series 1 after cooling down from fire.
Characteristics of connections after cooling down from fire temperature of $550^{\circ} \mathrm{C}$

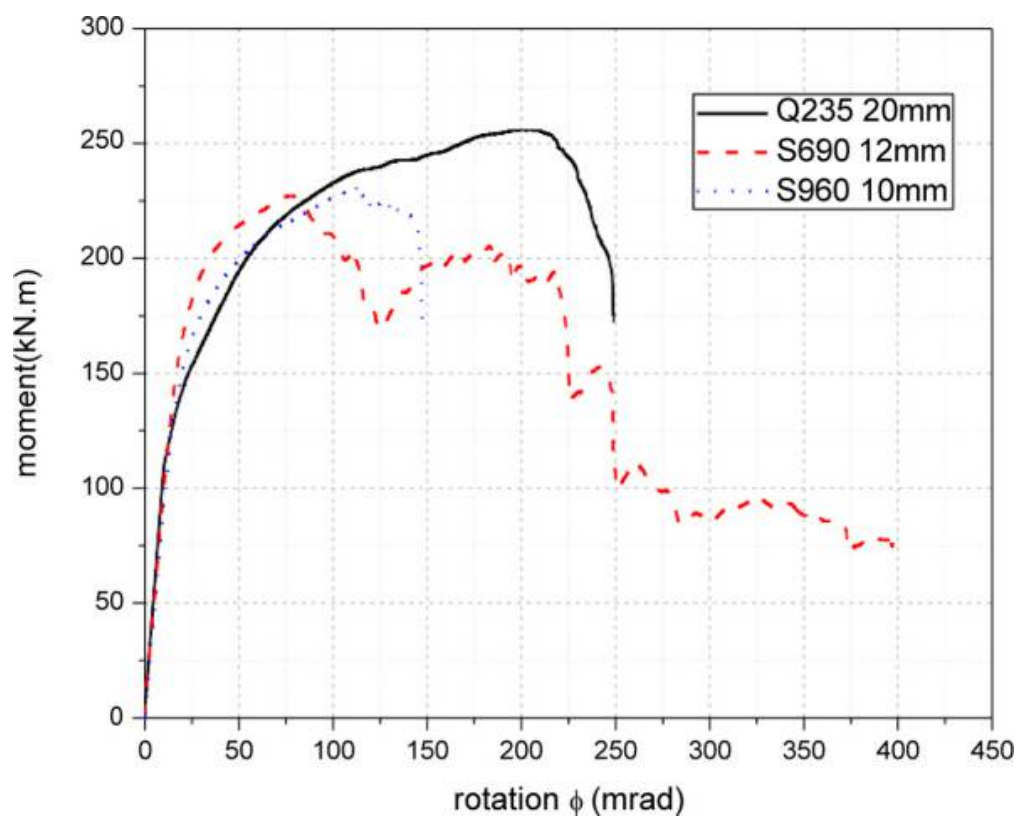

Performance assessment 
JSFE

8,2

\section{8}

Figure 4.

Moment-rotation comparison of connection Series 2 after cooling down from fire

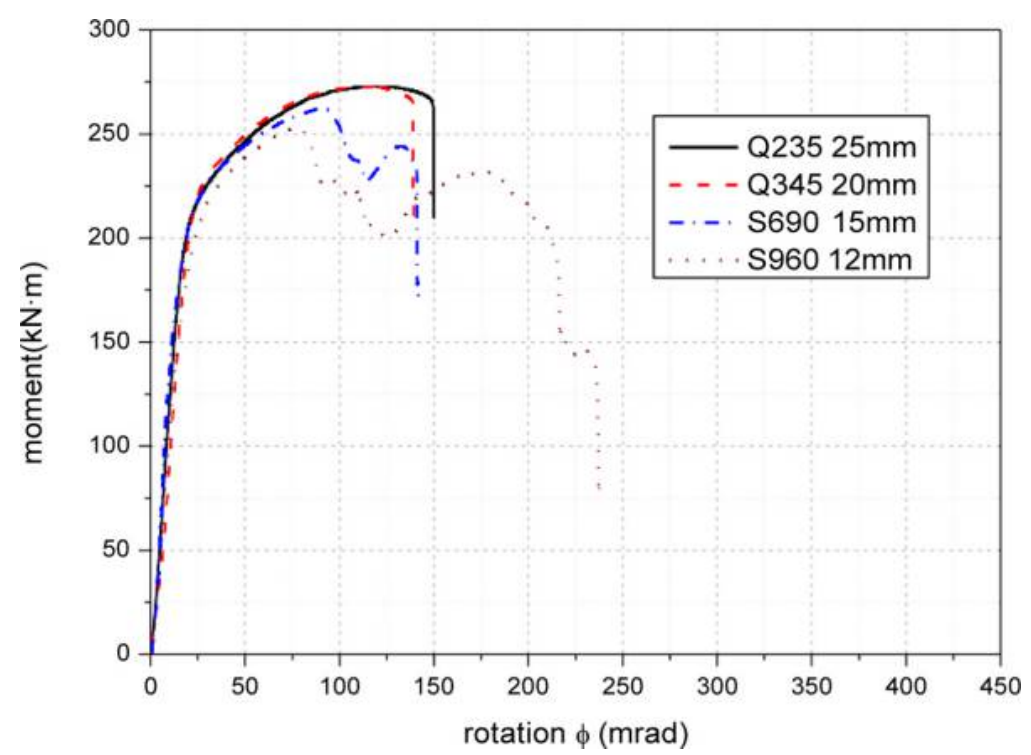

3.2 Contact interaction and analysis process

The contact pairs in this numerical model comprise the bolts-to-column flange, column flange-to-endplate, endplate-to-nuts and bolt shanks-to-bolt holes. The nuts were tied to the corresponding bolt shanks. Surface-to-surface contact, with a small sliding option, was used for all contact surfaces to fully transfer load. The penalty friction was used in the contact interaction property. To handle contact interaction problem, the whole analysis process comprised five analysis steps. In the first step, the bolts and endplate were temporarily restrained of all direction freedoms, and then a very small temporary load was applied to every bolt for restraining the bolt pairs temporarily. In the second step, the bolts and the endplate were freed from any temporary restraint. In the third step, the length of every bolt was fixed. In the fourth step, the temperature field for all components was set to $20^{\circ} \mathrm{C}$, where the material properties used in this model were post-fire mechanical properties of structural steels after cooling down from fire temperature of $550^{\circ} \mathrm{C}$. In the fifth step, an equivalent vertical surface traction converted from the vertical load was applied to the beam flange at the stiffener for loading. The first three analysis steps helped contact interactions to be established smoothly, which is effective to decrease calculation time and eliminate errors. The failure criterion used herein is based on deformation by assuming that cracking occurs when the ultimate strain $\varepsilon_{u}$ of the material (either endplate or bolt) is reached, as proposed by Coelho et al. (2002) and Coelho (2004).

\subsection{Material properties}

In this finite element modeling, the material properties of mild steels (including Q235 and Q345) after cooling down from fire temperature of $550^{\circ} \mathrm{C}$ are 90 per cent of their original mechanical properties at ambient temperature without fire exposure, according to the recommendation on post-fire remaining factor of S235 and S275 of British Standard 5950: Part 8 (BS Institution, 1998). The material properties of Grade 8.8 bolt assembly at ambient temperature without fire exposure input herein are in accordance with those reported by the University of Sheffield in literature (Hu et al., 2007, 2008; Hu, 2009) (Theodorou, 2003), and the 
remaining factors of mechanical properties of Grade 8.8 bolt assembly after fire reported by Lou et al. (2010) are used herein. The material properties of high strength steels S690 and S960 after cooling down from fire input in this finite element model are obtained by the experimental study presented in references (Qiang et al., 2012, 2013).

\section{Discussions}

4.1 Validation of numerical modeling against experimental results

4.1.1 Deformation at the end of test. The numerically simulated final deformation states of all endplate connections after cooling down from fire temperature of $550^{\circ} \mathrm{C}$ were compared with those obtained from the experimental study. Figures 5 and 6 present the comparisons of the final deformation state of connection 2-3 P (S690 $15 \mathrm{~mm})$ and its components after failure at ambient temperature after cooling down from fire temperature of $550^{\circ} \mathrm{C}$, as an example. It can be seen that good agreements exist on the final deformation of connection 2-3 P (S690 15 $\mathrm{mm}$ ) after fire. Although the current numerical model cannot simulate the fracture of the bolts, it is able to reveal the location where the fracture initiates and evolves, as shown in Figure 6. Similar conclusions can be drawn for all seven connection specimens after cooling down from fire.

4.1.2 Moment-rotation characteristic. The comparisons of numerical modeling and experimental study on the moment-rotation relationship of various endplate connections (both high strength steel endplate connections and mild steel endplate connections) after cooling down from elevated temperature of $550^{\circ} \mathrm{C}$ at ambient temperature were carried out, where good agreements exist in general on initial stiffness, load bearing capacity and the connection rotation at the maximum load level $\phi_{M \text { max. }}$. For example, Figure 7 illustrates the moment-rotation comparison of two connections 2-3 P and 2-4 A.
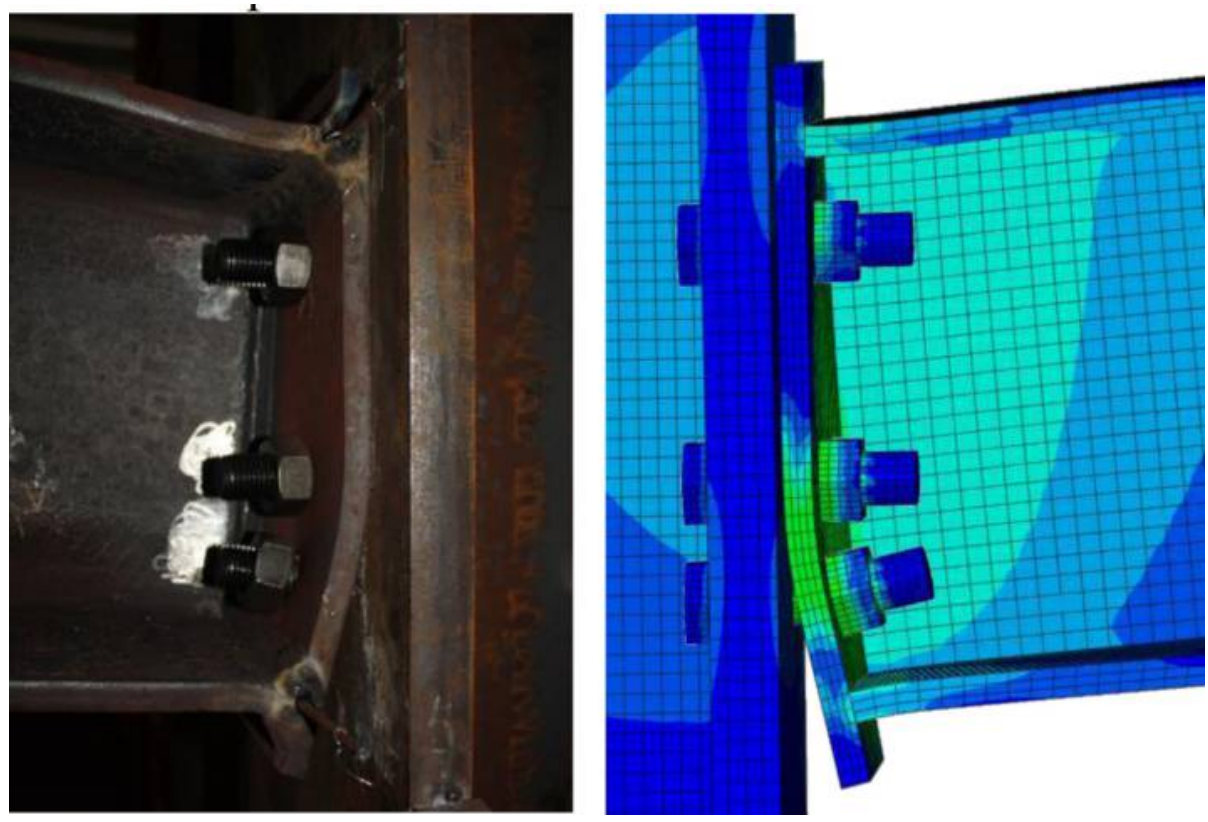

Figure 5.

Comparison on final deformation state of connection 2-3 P (S690

$15 \mathrm{~mm}$ ) after cooling down from fire temperature of $550^{\circ} \mathrm{C}$ 
JSFE

8,2

210

Figure 6.

Comparison on post-fire components of connection 2-3 P (S690 $15 \mathrm{~mm}$ ) after failure

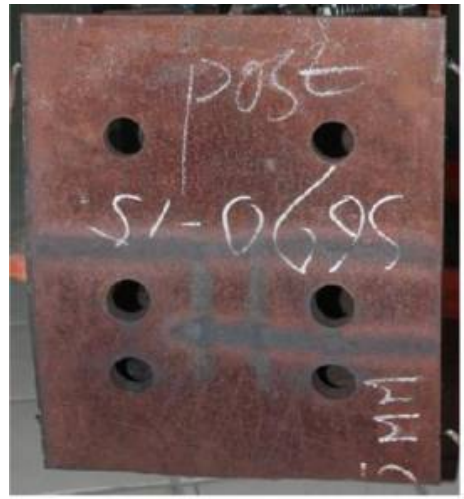

(a)

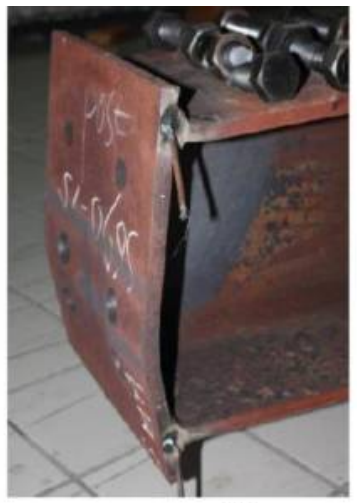

(b)
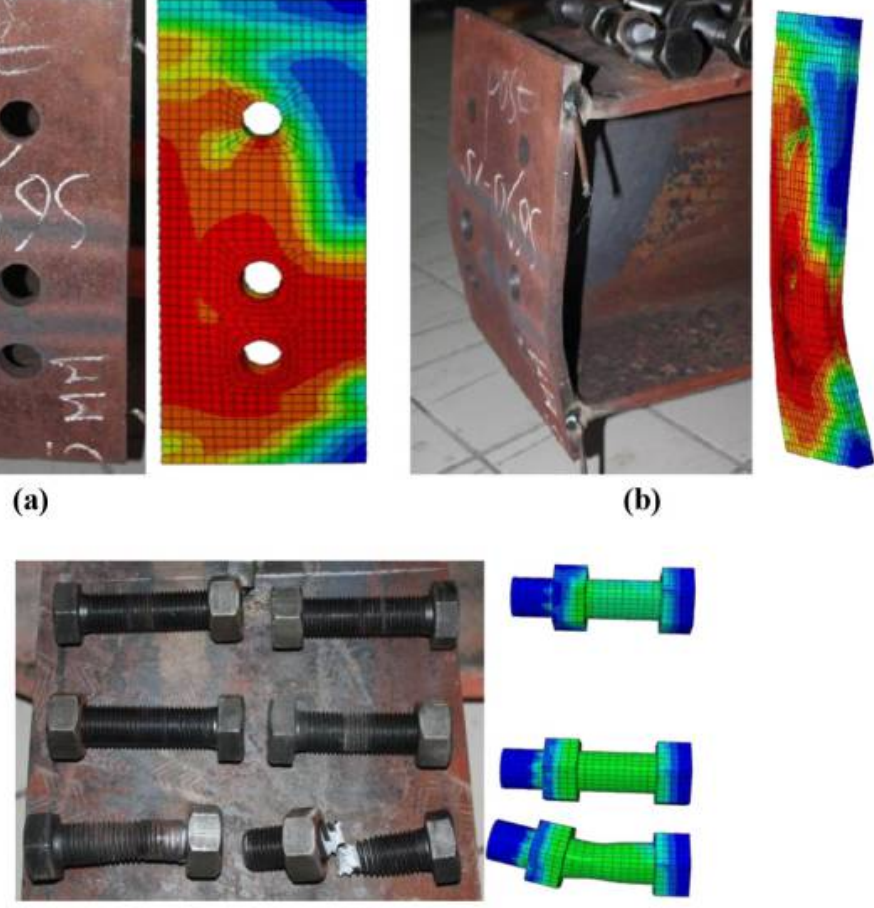

(c)

Notes: (a) Endplate front view; (b) endplate side view; (c) bolts

\subsection{Verification against Eurocode 3}

4.2.1 Failure modes. According to Eurocode 3 Part:1-8 (CEN, 2005), there are three failure modes for endplate connections. Mode 1 is complete yielding of endplate or column flange, Mode 2 is bolt failure with yielding of endplate or column flange and Mode 3 is bolt failure. Mode 3 is considered to be brittle and should be avoided in practical design. The failure modes of all endplate connections after fire obtained via theoretical analysis based on the rules of Eurocode 3 Part:1-8 (CEN, 2005) were validated against those from post-fire tests, as shown in Table IV. It can be observed that the predictions of Eurocode 3 agree very well with the test results.

4.2.2 Plastic flexural resistance. The plastic flexural resistances of all endplate connections at elevated temperature of $550^{\circ} \mathrm{C}$ are compared with the theoretical predictions of Eurocode 3 (CEN, 2005), as listed in Table V. It can be observed that good agreements exist between the theoretical predictions and experimental results. Via Ratio ${ }_{3}$, presented in Table V, it can be found that $M_{j_{\text {Rdtess }}, 1}$, obtained based on Zanon and Zandonini's (1988) definition, is generally smaller than $M_{j_{\text {Rdtest }}, 2}$, which is defined according to Weynand's (1997) proposal and the simplified method recommended by Eurocode 3.

The comparison of $M_{j_{\text {Rd test }}, 2}$ with the predicted plastic flexural resistance according to Eurocode 3 shows that the predictions of Eurocode 3 are generally at the conservative side when the test result is obtained based on Weynand's evaluation method. However, when the test-obtained plastic flexural resistance is defined according to Zanon and 


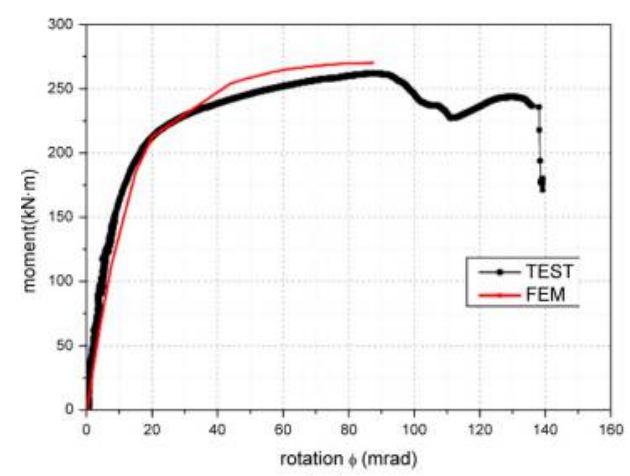

(a)

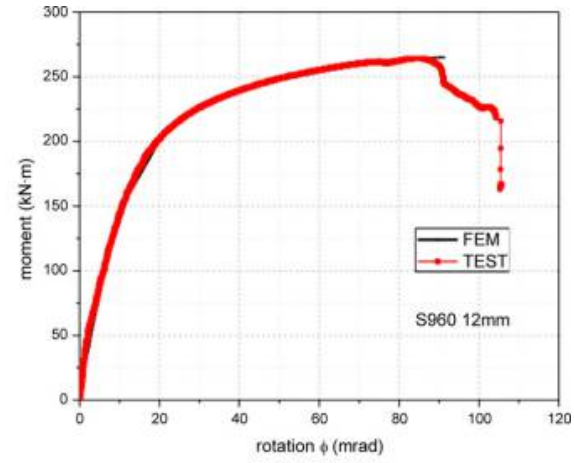

(b)

Notes: (a) 2-3 P (S69015 mm); (b) 2-4 A (S960 $12 \mathrm{~mm}$ )

Figure 7.

Moment-rotation comparison of endplate connections

\begin{tabular}{llcll}
\hline & \multicolumn{2}{c}{ Endplate } & \multicolumn{2}{c}{ Failure mode } \\
Test ID & Material & Thickness $(\mathrm{mm})$ & EC3 & Test \\
\hline 1-1 P & Q235 & 20 & Mode 1 & Mode 1 \\
1-2 P & S690 & 12 & Mode 1 & Mode 1 \\
1-3 P & S960 & 10 & Mode 1 & Mode 1 \\
2-1 P & Q235 & 25 & Mode 2 & Mode 2 \\
2-2 P & Q345 & 20 & Mode 2 & Mode 2 \\
2-3 P & S690 & 15 & Mode 2 & Mode 2 \\
2-4 P & S960 & 12 & Mode 2 & Mode 2
\end{tabular}

Table IV. Failure modes of endplate connections after cooling down from $550^{\circ} \mathrm{C}$

Zandonini's method, the predictions of Eurocode 3 are not as conservative as the former, but still on the conservative side in general. This validates that the accuracy of Eurocode 3 is acceptable when used to predict the plastic flexural resistance of endplate connections after fire, no matter if the endplate is made of mild steels or high strength structural steels.

\section{Conclusion}

The following conclusions can be drawn from this experimental and numerical study:

- The post-fire load bearing capacity and rotation capacity of endplate connections are dependent on the combination of endplate material and endplate thickness.

- In endplate connections, a proper design using a thinner high strength steel endplate can achieve the same failure mode, similar residual load bearing capacity and comparable or even higher rotation capacity after cooling down from fire, in comparison with a connection with thicker mild steel endplate.

- It is found that a high strength steel endplate connection can regain more than 90 per cent of its original load bearing capacity after cooling down from fire temperature of $550^{\circ} \mathrm{C}$. This important finding is very promising for the reuse of steel structures with high strength steel endplate connections after fire. 
JSFE

8,2

212

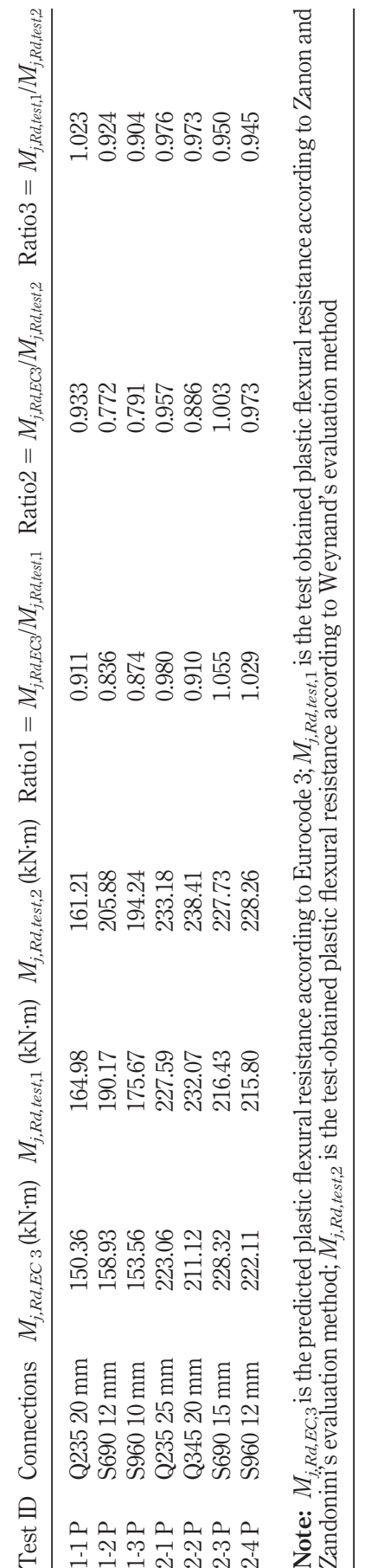

Table V.

Evaluation of plastic

flexural resistance after cooling down from $550^{\circ} \mathrm{C}$ 
- The accuracy of Eurocode 3 for plastic flexural resistance of endplate connections is validated to be acceptable when used to predict post-fire performance, no matter if the endplate is made of mild steels or high strength structural steels.

- The challenge of numerical modeling contact interactions considering material and geometric non-linear effects has been solved successfully.

- This finite element analysis gives reasonable accuracy compared with the experimental results, providing an efficient, economical and accurate tool to assess the post-fire performance of high strength steel endplate connections.

- The parametric study can be further performed using this numerical model to investigate the post-fire performances of high strength steel endplate connections after cooling down from various fire temperatures, via inputting proper mechanical properties of high strength steels after fire, for instance, that of S460, S690 and S960 after cooling down from various fire temperatures.

- By the present modeling method, the first critical component of endplate connections can be identified, but the occurrence of component fracture and the subsequent failure of other components cannot be predicted. To improve this numerical simulation, solid modeling of welds and taking into account fracture features on components are of importance in future numerical study.

\section{References}

ABAQUS (2013), Analysis User's Manual, 6.13 Version, Dassault Systemes Simulia Corp, Providence, RI.

BS Institution (1998), "Structural use of steelwork in building”, Part 8: Code of Practice for Fire Resistant Design, London.

CEN (2005), "Eurocode 3: design of steel structures", Part 1-8: Design of Joints, Brussels.

Coelho, A.M.G. (2004), "Characterization of the ductility of bolted end plate beam-to-column steel connections", PhD thesis, University of Coimbra, Coimbra.

Coelho, A.M.G., Bijlaard, F.S.K. and Silva, L.S.D. (2002), "On the deformation capacity of beam-tocolumn bolted connections in European convention for constructional steelwork - technical committee 10: structural connections (ECCS-TC10)".

Della Corte, G., Landolfo, R. and Mazzolani, F.M. (2003), "Post-earthquake fire resistance of moment resisting steel frames", Fire Safetv Journal, Vol. 38, pp. 593-612.

$\mathrm{Hu}, \mathrm{Y}$. (2009), "Robustness of flexible endplate connections under fire conditions", $\mathrm{PhD}$ thesis, University of Sheffield, Sheffield.

Hu, Y., Davison, J.B. and Burgess, I.W. and Plank, R.J. (2007), Comparative Study of the Behaviour of BS 4190 and BS EN ISO 4014 Bolts in Fire, ICSCS 2007, Manchester, pp. 587-592.

Hu, Y., Davison, J.B., Burgess, I.W. and Plank, R.J. (2008), "Experimental study on flexible end plate connections in fire", 5th European Conference on Steel and Composite Structures, Graz, pp. 1007-1012.

Lou, G.B., Yu, S. and Wang, R. (2010), "Experimental study of mechanical properties of high-strength bolts after fire", Structures in Fire: Proceedings of the 6th International Conference, pp. 679-686.

Pucinotti, R., Bursi, U.S. and J.F. Demonceau (2011), "Post-earthquake fire and seismic performance of welded steel-concrete composite beam-to-column joints", Lournal of Constructional Steel Research, Vol. 67 No. 4, pp. 1358-1375.

Qiang, X. (2013), "Behaviour of high strength steel endplate connections in fire and after fire", $\mathrm{PhD}$ thesis, Delft University of Technology, Delft. 
JSFE 8,2

214

Qiang, X., Bijlaard, F.S.K. and Kolstein, H. (2012), "Post-fire mechanical properties of high strength structural steels S460 and S690", Engineering Structures, Vol. 35, pp. 1-10.

Qiang, X., Bijlaard, F.S.K. and Kolstein, H. (2013), "Post-fire performance of very high strength steel S960”, Lournal of Constructional Steel Research, Vol. 80, pp. 235-242.

Tao, Z., Han, L.H., Uy, B. and Chen, X.A. (2011), "Post-fire bond between the steel tube and concrete in concrete-filled steel tubular columns", Iournal of Constructional Steel Research, Vol. 67, pp. 484-496.

Theodorou, Y. (2003), "Mechanical properties of grade 8.8 bolts at elevated temperatures”, Master's dissertation, University of Sheffield, Sheffield.

Weynand, K. (1997), Sicherheits-Und Wirtschaftlichkeitsuntersuchungen zur Anwendung Nachgiebiger Anschlüsse im Stahlbau, Heft 35, Shaker Verlag, Aachen.

Witteveen, J., Twilt, L. and Bijlaard, F.S.K. (1976), "Theoretical and experimental analysis of steel structures at elevated temperatures", International Association for Bridge and Structural Engineering, Tokyo.

Yang, H., Han, L.H. and Wang, Y.C. (2008), "Effects of heating and loading histories on post-fire cooling behaviour of concrete-filled steel tubular columns", Iournal of Constructional Steel Research, Vol. 64 No. 5, pp. 556-570.

Zanon, P. and Zandonini, R. (1988), "Experimental analysis of end plate connections", Proceedings of the State of the art Workshop on Connections and the Behaviour of Strength and Design of Steel Structures, Cachan, pp. 41-51.

Corresponding author

Xu Jiang can be contacted at: jiangxu@tongji.edu.cn

For instructions on how to order reprints of this article, please visit our website:

www.emeraldgrouppublishing.com/licensing/reprints.htm

Or contact us for further details: permissions@emeraldinsight.com 